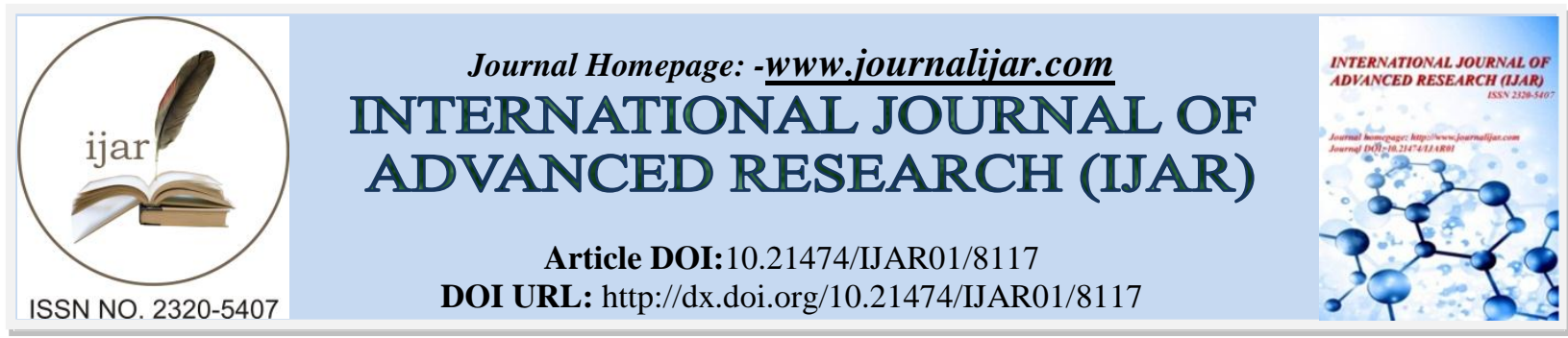

RESEARCH ARTICLE

\title{
AN EMPIRICAL OF INVESTMENT AND GOVERNMENT SPENDING ON POVERTY LEVELS IN PAPUA PROVINCE THROUGTH ECONOMIC GROWTH AND MIGRATION.
}

\author{
Abdul Rasyid ${ }^{1}$, Muhammad Yunus Zain ${ }^{2}$, Muhammad Yusri Zamhuri ${ }^{3}$ and Sultan Suhab ${ }^{4}$ \\ 1. Faculty of Economics, University of Yapis, Papua, Indonesia. \\ 2. Faculty of Economics, University of Hasanuddin, Indonesia.
}

\section{Manuscript Info}

(..........................

Manuscript History

Received: 01 October 2018

Final Accepted: 03 November 2018

Published: December 2018

Keywords:-

investment, goverment expendicture ,economic growth,, Migration, level poverty.

\begin{abstract}
This study aims to measure both the direct effectand indirect effect of investment and goverment on poverty. We regress indirect effect of the respective varables trougth economic growth, and migration.

In this study Structural Equation Model (SEM) is applied. We use panel data of 29 districts within Papua Province for periode of 20072017. Then we run regression by utilizing analisys of moment structure (AMOS).

The resarch reveal the results investment have no effect on poverty both directly and indirectly through economic growth. An then result reveal that investment have significant effect on poverty through migration. In addition, government spending does not have effect on poverty both directly and indirectly through economic growth. In spite of that government spending have significant effects on poverty through migration. Thus, we may generalize that investment and goverment spending have yet effect on reduceng poverty rate, both through economic growth, community empowerment and through labor absorption.
\end{abstract}

Copy Right, IJAR, 2018,. All rights reserved.

\section{Introduction:-}

The poverty phenomenon has been going on for a long time, although various efforts have been made in mitigating it. Until now there are still many people in the world who live below the poverty line with incomes of less than two dollars a day and even earn only one dollar per day.

Discussing the problem of poverty is not only a local, regional and national problem but has become a global movement and breakthrough. This can be observed from several developing issues, namely: Meeting in the World Summer on Copenhagen Social Development 1995, meeting at the Forum of the Food Summit at Rome on June 12, 2002, The 2001 United Nations (UN) Millennium Summit was morally binding that all countries, both developed and developing/poor countries to halve the number of poor people in 2015.

Likewise in Papua Province, various efforts have been made by the government by continuing to encourage the pace of investment and the addition of government spending. As with other provinces in Indonesia, poverty is a reality of the problem that is still experienced by the Papua Province. Poverty in the eastern part of Indonesia is a complex problem. The significant difference in poverty levels between this region and other regions in Indonesia is not sufficiently explained through individual or household characteristics.

Corresponding Author:-Abdul Rasyid.

Address:- Faculty of Economics, University of Yapis, Papua, Indonesia. 
Based on BPS data in 2015 for Food Poverty Lines of the Urban, Rural and Urban Provinces plus Rural Areas that, for semester 1 of 2015 the urban poverty line of the Papua Province ranged from 289,615 people, while in the second semester of the same year it rose to 290,712 people. While the rural poverty line for semester 1 of 2015 ranged from 307,526 people, while in semester 2 of the same year it increased to 310,937 people. Furthermore, the urban rural poverty line for semester 1 of 2015 was 30,807 people, whereas in the same semester 2 years it increased to 305,579 people. This shows that, the percentage of the food poverty line in Papua Province shows an increase in the semester.

The character of poverty in every place must be different. This really depends on the source of poverty it self. The source of poverty basically includes; conditions and conditions of nature, structural levels of social and culture and government policies. The source of poverty basically includes; conditions and conditions of nature, structural levels of social and culture and government policies, From the social side, in Papua social value is far hig her than economic value. So high social value so that almost every house in Papua not only contains a nuclear family, father, mother and child but contains other large families who are still classified as close family. As a result, salary and income are not enough. to finance home needs for a month, Income from farming and raising live stock or salaries that should have a large economic value, finally it becomes worthless, in the end there is no income left to save or save.

Based on the January 2016 BPS Socio-Economic Report that the Papua Province has the largest percentage of poor people from ten provinces in Indonesia classified as Provinces which have the largest percentage of poor people. In addition, it was also explained that, in some regions, the percentage of poverty increases from the previous period, such as Papua Province and Aceh Province.

Poverty is a very basic problem and always appears in the development process in various parts of the world in this world, especially for developing countries including Indonesia. In this regard, hence through investment growth and government expenditure, it is expected to encourage improvements in various aspects of people's lives through the trickle down effect, especially in the framework of overcoming the problem of poverty.

One indicator of the success of a region is the management of Regional Finance, where the existence of Law No. 22 of 1999 Jo. Law No. 32 of 2004 and Law No. 25 of 1999 Jo. Law No. 33 of 2004, it gives a very large authority to the regions to manage their sources of income and allocate them to improve community welfare and Empowering of local administration. Regional Revenue and Expenditure Budget is a regional government financial operational plan in which one party describes the highest estimated expenditure to finance regional activities and projects. On this basis, regional autonomy in regional financing cannot be interpreted that the regional government must be able to finance all expenses with funds from Regional Original Revenue.

In principle, the main goal of an economic policy is to create prosperity, One of the most important measures of prosperity is income. Prosperity is created because of income generating activities. Total income is the level (amount) of community income achieved in a region. The income level can be measured from the total regional income and the average income of the community in the region. Regional development must be related to increasing community income in the region, what is meant is the average income (income per capita) of the community, (Tarigan, 2005).

Indeed, it is realized that the rate of investment growth cannot necessarily guarantee equal distribution of income. The facts show that the income of the people in a country is not always even, This condition will result in a gap.

Horst Siebert (1969) in his theory, mentions that, the occurrence of differences in the level of economic growth between regions is caused by internal and external influences. Internal factors in question include economic potential and resources owned by each region, availability of facilities and infrastructure to support economic activities such as transportation facilities, market availability for output produced by the region concerned and so on.Todaro, 1999 says that, basically economic development has four main dimensions, namely. (1) economic growth, (2) poverty reduction, (3) economic change or transformation and to (4) sustainable development from an agrarian society to an industrial society. Therefore structural transformation is a prerequisite for increasing and sustaining growth and reducing poverty as well as supporting the sustainability of development it self. 
The problem of poverty in the Papua Province has become a serious concern. At least for two reasons, First, that during the last few years (special autonomy era) Papua Province has recorded a relatively high rate of investment growth but not comparable with the decline in poverty, second, the highest poverty rate is still recorded by the Papua Province.

As a result of the level and rate of unbalanced development, then without a specific policy and business strategy with various constraints and development trends that exist,the gap will continue to grow, (Kartasasmita, 1996). The inequality of income distribution among layers of society not only takes place nationally, however it also occurs partially or between regions, (Dumairy, 1999).

On the other hand, investment is actually expected to reduce poverty. Investment activities allow a society to continuously improve economic activities and employment opportunities, increase national income and improve people's lives. This role comes from three important functions of investment activities, namely investment is one component of aggregate expenditure. So that the increase in investment will increase aggregate demand, national income and employment opportunities. The increase in capital goods as a result of investment will increase production capacity and investment is always followed by technological developments.

As an economic buffer, investment in the Papua Province shows an encouraging situation. In 2013, total investment in Papua reached Rp. 304 billion (based on current prices), whereas in 2012 only Rp. 45.8 billion. (based on current prices). The investment is carried out by the government and the private community. However, the role of government investment is still relatively small.

To find a solution to the resolution of poverty in the Papua Province, it is a good idea to know earlier the characteristics of poverty. First, the poverty level gap between regions in Indonesia is very high. Second, most of the poor are in rural areas and most work in the agricultural sector with relatively low wages. Third, many residents who enter and enter between the poor become almost poor and vice versa due to government policies.

Economic and social inequalities generally have an adverse economic and social impact. The income gap in a region will cause various problems, such as an increase in migration flows that move from poorer regions to more economically advanced regions, or areas that allow Migration to get jobs or opportunities to open businesses. But the flow of uncontrolled migration can cause various problems. such as slum settlement, crime, providing jobs with an adequate amount, and so on. In addition, the negative impact that can arise due to migration flows is the income gap, the emergence of social jealousy, which can also cause negative excesses on the social and political life of the community.

Based on this phenomenon, poverty in the Papua Province needs to get full attention from the government as a problem that must be dealt with immediately in efforts to alleviate poverty.

\section{Literature review:}

Development inequality between regions is a common aspect that occurs in the economic activities of a region. This imbalance is basically caused by differences in the content of natural resources and differences in the demographic conditions found in each region. As a result of these differences, the ability of a region to encourage the development process also becomes different. Therefore, it is not surprising if in each region there are usually developed regions (Underdeveloped Region) and developed regions. The occurrence of inequality between regions has implications for the level of community welfare between regions. Therefore, the aspect of inter-regional development disparities also has implications for the formulation of regional development policies carried out by regional governments. Safrizal (2008) has identified the causes of development inequality between regions as follows (1) differences in natural resource content (2) differences in demographic conditions (3) lack of smooth mobility of goods and services (4) concentration of regional economic activities (5) allocation development funds between regions (government expenditure).

Various studies discuss the characteristics of the poor, this indicates that research has not focused on local characteristics. There are several other variables that are very influential but have not been widely studied. Therefore research on the characteristics of the poor will become increasingly important if placed in a regional context that indicates the existence of spatial variations in poverty levels. Centralistic policies without taking into account spatial aspects can be less effective (Blank, 2004). 
Robert Chambers (1983) asserts that the factors that cause poverty are; the poverty loop of loss of rights or wealth that is difficult to return to, perhaps due to the insistence of needs that exceed the threshold of strength, for example expenditure that has been calculated before, but the amount is very large, or suddenly faced with a great crisis. Normally the need that drives someone who is in poverty is related to five things; customary obligations; disaster; physical disability, unproductive expenditure and extortion.

Although development continues to change along with historical experience in the era of the 1950s and 1960s which shows that development is oriented to the increase in Gross National Product but has not been able to solve development problems fundamentally. As Agussalim (2009) explains that the emergence of ideas to reconstruct the conception of development, at least triggered by several reasons. First, economic growth (economic growth) achieved by a number of countries for 2-3 decades, turned out not to be accompanied by equal distribution and improvement in income distribution. The inequality (coefficient) of income distribution in many countries tends not to shift significantly for decades.

Related to the problem of economic development, Todaro (2000) said that "the success of economic development is shown by three (3) core values, namely: (1) the development of the community's ability to fulfill basic needs (Basic needs), (2) increased self-esteem (self esteem) as a human society, and (3) increasing the ability of the people of freedom (freedom from servitude) which is one of human rights. Thus it can be realized that the notion of economic development is very broad, this is not just how to increase the Gross National Product (GNP) per year, but economic development can also be interpreted as activities carried out by a country to develop economic activities and levels the community.

The theory of regional income disparity was put forward by Jeffrey G. Williamson who analyzed income distribution and economic growth at the regional (regional) level in a country, evidently found in a country there is a high per capita income area which is always followed by a group of medium and low income per capita. If the difference between high and low income per capita is very large, it means that there is a high income disparity. It was also found that in the initial stages of development, economic growth appeared to be more evenly distributed between regions, but in a further stage, economic growth between regions revealed increasingly large differences, which meant that income disparities between regions grew.

Adelman I and Morris T C in Arsyad (1999) suggest that there are eight (8) factors that cause inequality of income distribution (income disparity) including 1). High population growth which results in a decrease in per capita income. 2). Inflation where money income increases but is not followed in proportion to the increase in production of goods. 3). inequality in development between regions. 4). Very much investment in capital intensive projects, so the percentage of capital income from assets is greater compared to the percentage of income that comes from work, so unemployment increases.

Economic theory defines or defines investment as expenditures to buy capital goods and production equipment with the aim of replacing and mainly adding capital goods in the economy that will be used to produce goods and services in the future. The investment commonly referred to as the term investment or capital formation is the second component that determines aggregate expenditure. Furthermore Boediono (2001) defines investment as an expenditure by the producer sector (private) for the purchase of goods and services to add to the stock used or to expand the plant.

Investment is a concept of flow (flow concept), because it is calculated for one internal period. But investment will affect the amount of capital stock available for a certain period. Additional stock of capital goods is equal to the investment expenditure of the previous period. Therefore all expenditures carried out and intended as investment values in a given year can be classified as investments (capital formation or investment). The investment aims to increase production capacity in the economy and replace depreciated capital goods. If gross investment is reduced by depreciation value, a net investment is obtained.

Investment allows a society to continually improve economic activities and employment opportunities, increase national income and improve the lives of the people, This role comes from three important functions of investment activities, namely investment is one component of aggregate expenditure, so that an increase in investment will increase aggregate demand, national income and employment. The increase in capital goods as a result of 
investment will increase production capacity. The effect is on the level of income of the community, so that the opportunity for the community to escape from the abyss of poverty is increasingly open.

Until now, there has not been an absolute definition of poverty. Therefore, an understanding of poverty needed in the effort of a planning process to reduce the poor can be seen from various perspectives. For example from the perspective of writers or from the point of view of various disciplines such as: economics, social, political, cultural, and anthropological or also from the point of view of various international institutions such as the World Bank, United Nations Development Program (UNDP), and Asian Development Bank ( ADB). There are wide variations in defining poverty, but all these definitions can be categorized into one category only, namely: 1. Poverty is objectively meaningful, has less than the absolute minimum needs that must be met. 2 . Poverty is having less than other people in a society. 3. Poverty is the feeling that you don't have enough to continue to live Hagenaars and Vos (1997).

Poverty according to the first category is something absolute and poverty according to the second category can be something absolute and relative. The categorization of poverty based on absolute and relative concepts according to O "Boyle (1998) cannot be avoided because basically humans are individual beings as well as social beings.

In line with Shubert's thinking and point of view (in Poli, 1998), according to Mubyarto (1994) that, poverty can be divided into two types, namely: absolute poverty and relative poverty. Absolute poverty is poverty which is associated with not meeting the minimum basic needs for a decent life because it is caused by the low level of income of a person / family. Poverty in absolute terms is determined based on the inability to meet minimum basic needs.

In general, poverty is a person's inability to meet basic basic needs for every aspect of his life. If viewed from a macroeconomic perspective, the concept of poverty is measuring per capita income. This concept began to develop in the 1960s, then this concept developed widely on aspects of welfare.

As Poli (2006) states that poverty can be divided into four dimensions of poverty which have a causal relationship with each other, namely 1 . Economic dimensions, namely the lack of ability to meet basic needs due to low income. This deficiency is called the lack of choice. 2. The political dimension, namely the lack of ability to express and be heard by the authorities. This deficiency is called lack of voice. 3. Social dimensions, namely the low social status on the scale of community assessment. This deficiency is called lack of status. 4. Psychological dimensions, namely lack of confidence. This deficiency is called lack of confidence.

From the various meanings of poverty mentioned above, there are at least four dimensions of poverty which can be formulated from various definitions of poverty, namely: The first dimension, is the material dimension in the form of food shortages and employment with hunger or lack of food. The second dimension is the psychological dimension, among others: powerlessness, voicelessness, depedency, shame and humiliation. The third dimension, is the dimension of access to infrastructure services that is practically not owned. The fourth dimension, is the asset / ownership dimension, practically does not have assets as capital to properly carry out their lives.

According to the Central Statistics Agency (BPS), poverty is the inability to meet minimum standards of basic needs which include food and non-food needs. Comparing the level of consumption of the population with the poverty line or the amount of rupiah for consumption per month.The definition according to UNDP is the inability to expand life choices, including by including the assessment of the absence of participation in public policy making as an indicator of poverty.

The concept of poverty used in Indonesia is reflected in Presidential Regulation No. 15 of 2009 concerning Poverty Reduction Coordination by using a rights-based approach to understanding poverty, that is, a condition in which a man or woman is not fulfilled basic rights in maintaining and developing a dignified life. The rights-based approach based on government regulations implies that the state is obliged to respect, protect and fulfill basic rights, as stated in the 1945 Constitution. These basic rights include; food, health, education, employment, housing, clean water, natural resources, security, and participation in social and political life. From some of the poverty theories illustrate the existence of two kutup about the theory of poverty, namely Neo-Liberal and Social Democracy. 
The theory of Neo-Liberal originates from the writings of Thomas Hobbes, John Luck and John Stuart Mill who call for individual freedom as the most important component in society. while Adam Smith through his famous work The Wealth of Nations (1776), besides that Laissez Fiaire as the initiator in the economy and continued by Frederik Hayek in his work The Road to Serfdont (1945), made it as a reference and reference by Neo-Liberals who put forward the principle of Laissez Fiaire in the concept of poverty.

In contrast to the Social Democratic approach, which states that the causes of poverty are not individual problems but structural problems as the main focus of the causes of poverty, this approach states that poverty occurs due to inequality and the clogging of certain groups' access to social resources .

Axioms or principles for measuring poverty, namely: anonymity, independence, meaning that the scope of poverty cannot depend on who is poor or on whether the country has a large or small population. The principle of distributional sensitivity states that with everything else constant, if you transfer income from the poor to the rich, then the economy will become poorer.

One way to measure poverty applied in Indonesia is to measure the degree of income inequality among the poor, such as the Gini coefficient between the poor (GP) or the coefficient of income (CV) variation among the poor (CVP). The Gini coefficient or CV between these poor people is important to know because the impact of economic shocks on poverty can be very different depending on the level and distribution of resources among the poor.

\section{Theories of Inequality and Poverty:-}

In general, poverty is a person's inability to meet basic basic needs for every aspect of his life. If viewed from a macroeconomic perspective, the concept of poverty is measuring per capita income. This concept began to develop in the 1960s, then this concept developed widely on aspects of welfare.

Living in poverty not only lives in a lack of money and a level of income, but there are many other things such as; low level of health and education, unfair treatment in law, vulnerability to threats of criminal acts, powerlessness in determining the way of life it self (Suryawati: 2005).

Yao (2007) mentions poverty as a lack of income, food, housing, employment opportunities, or physical assets based such as; livestock and land. Poverty also means the lack of access to various facilities such as; drinking water facilities, health facilities when needed or inability to read and write.

As Poli (2006) states that poverty can be divided into four dimensions of poverty which have a causal relationship with each other, namely 1. Economic dimensions, namely the lack of ability to meet basic needs due to low income.This deficiency is called the lack of choice. 2. The political dimension, namely the lack of ability to express and be heard by the authorities. This deficiency is called lack of voice. 3. Social dimensions, namely the low social status on the scale of community assessment. This deficiency is called the lack of status. Psychological dimensions, namely lack of confidence. This deficiency is called lack of confidence.

Growth gaps and income disparities between regions are unavoidable phenomena, because the region's potential, conditions, and characteristics vary or vary from one another. Regional characteristics vary physically, economically, socio-cultural, landscape, environment, and others.

The emergence of the Williamson study (1965), has also encouraged some experts to conduct studies on development inequality between regions in Indonesia. In this regard Tambunan (2003) explains that there are enough studies that analyze the factors that cause economic inequality between provinces or regions in Indonesia, including from Esmara (1975), Sediono and Igusa (1992), Azis (1989), and Williams (1989), Sondakh (1994), Ibrahim (1974), Up! and Handoko (1988), Arsyad (1999), Akita and Lukman (1999), and Safrizal (1997, 2000).

The conclusion of all these studies is that the main factors causing economic inequality between provinces in Indonesia include; First, the concentration of regional economic activity. Second. Investment allocation. Third, the low level of factor mobility between regions. Fourth, differences in natural resources (SDA) between provinces. Fifth, differences in demographic conditions between regions. Sixth, the lack of smooth trade between provinces. These factors are considered very influential on the high rate of poverty. 
According to (Nurske, Jingan, 2000 and Kuncoro, 2003) that, countries or regions with high poverty levels are generally entangled in what is called the cycle of poverty, while the causes of poverty are: 1). Poverty is due to the unequal pattern of resource ownership which results in an unequal income distribution, 2). There is a difference in the quality of human resources so that it has low productivity, so the gains obtained are also low. The low quality of these resources is usually caused by low levels of education, 3). Poverty due to differences in access to capital. These three causes are the cause of the birth of the concept of the poverty vicious circle (Vicous, Circle Poverti).

\section{Effect of Investment on Poverty Levels:-}

Economic theory defines or defines investment as expenditures to purchase capital goods and production equipment with the aim of replacing and mainly adding capital goods in the economy that will be used to produce goods and services in the future. Investment, commonly referred to as the term investment or capital formation, is the second component that determines aggregate expenditure. Furthermore Boediono (2001) defines investment as an expenditure by the producer sector (private) for the purchase of goods and services to add to the stock used or to expand the plant.

While the investment that is affected is investment that is influenced by national income, meaning that national income will increase the income of the community and then the high income of the community will increase the demand for goods and services. Then the profits from the company will increase and this will continue to encourage more investment. Therefore all expenditures carried out and intended as investment values in a given year can be classified as investments (capital formation or investment).

Investment allows a society to continuously improve economic activities and employment opportunities, increase national income and improve the lives of the people. This role comes from three important functions of investment activities, namely investment is one component of aggregate expenditure, so that an increase in investment will increase aggregate demand, national income and employment opportunities, the increase in capital goods as a result of investment will increase production capacity.

\section{Effect of Government Expenditures on Poverty Levels:-}

In every government expenditure, it is always accompanied by government policy. This means that if the government has formulated a policy to buy goods and services, then government expenditure reflects the amount of costs that must be spent by the government to implement the policy.

In macro theory, government expenditure in the real sense can be used as an indicator of the amount of government activity financed by government spending. The point is, that the greater and more government activities, the greater the government expenditure concerned. Government expenditure consists of three (3) main items which can be classified; 1) Government expenditure for the purchase of goods and services. 2) Government expenditure for employee salaries and, 3) Government expenditure for transfer payments. (Boediono, 1999).

The development model of the development of government expenditure was introduced and developed by Rostow and Musgrave, which links the development of government spending with the stages of economic development that are distinguished between the initial, intermediate and advanced stages.

Wagner stated that in an economy if per capita income increases, government spending will increase relatively, mainly because the government must regulate relationships that arise in society, law, education, recreation, culture and so on.In connection with Wagner's law, it can be seen some of the causes of increasing government spending, namely increasing the functions of defense and security, increasing welfare functions, increasing banking functions and increasing development functions.

Development financing carried out by the government is inseparable from the State Budget or the Regional Expenditure Budget. Government involvement in the economy always increases from year to year or what is called the Law of Ever Increasing State Activity from Wagner.

The amount of government expenditure can reflect the magnitude of the government's role in the economy. In general, the function or role of government can be categorized into functions of allocation, distribution and stabilization.Models that can be used to explain the role of government in the economy can be found from the Rostow and Musgrave models. Rostow and Musgrave connect government spending with the stages of economic 
development consisting of the initial, intermediate and advanced stages. In the early stages of economic development, the role of the government was greater because it had to provide education, health, transportation and so on.

\section{Effect of Economic Growth on Poverty:-}

Research on economic growth, income inequality and poverty also yields several thoughts. Khan (2007, 18-19) has conducted research on studies conducted by UNDP and ILO / SIDA. His results show that rapid economic growth and the reduction of the forces of inequality are the essence of health and a reduction in the sustainability of poverty.According to him, even increasing inequality can offset the benefits of growth rates insofar as it still concerns poverty reduction. However, this condition continues even though it has been improved, while the equality in income distribution is uncertain to guarantee poverty reduction when growth weakens. Equations in this context at least maintain an unchanging part of additional income for the poor, rather than suppressing the overall indicator of income distribution.

Rober Lucas (1988) development of Paul Romer (1986, 1987) proposes a model of economic growth in which the effects of human capital are even greater even in the model of Uzawa (1965). The increase in all scale of production factors proportionally can cause greater than the proportional increase in output. On the contrary the impact can add more than one and the impact of human capital can be greater than the share of labor.

Oyugi (Oyugi, 2008, 19-20) in his study asserted that growth is considered the key to poverty reduction, based on the results of his research conducted in Botswana, Kenya and Namibia which showed that economic growth in these countries had failed to trickle down for the benefit of every citizen and to reduce poverty. This is indicated by the existence of a high poverty rate in Botswana, even though the rate of economic growth is high and sustainable at 7 percent.

\section{Effect of Migration on Poverty:}

The influence of migration and transmigration programs or population movements has been known since the Dutch colonial era, with the term colonization. The implementation of the colonization program began in 1905 (Heeren, 1979). Furthermore, after the independence period, the colonization program continued, known as transmigration. Whereas the migration of people carried out on their own will is called Migration and this type is happening in Papua Province.Menurut Dwiyanto (2003), penyelenggaraan transmigrasi pada era otonomi daerah menimbulkan berbagai macam konflik, seperti konflik antara masyarakat dan pemerintah daerah, konflik antarmasyarakat, dan konflik antardaerah. Latar belakang munculnya konflik antara lain (1) persoalan sosial, seperti perselisihan warga; (2) persoalan politik, seperti konflik antara kepala daerah dan DPRD, konflik antar-instansi, konflik antara pendukung partai politik; dan (3) persoalan ekonomi, seperti sengketa tanah, perselisihan pengelolaan sumber daya alam,konflik perburuhan.

Therefore, the success achieved by transmigrants who are not accompanied by the progress of the local population is a problem in the integration between transmigrants or immigrants and indigenous people due to social jealousy. Conflicts that occur naturally can disrupt the process of regional development and community welfare. Therefore, the role of local government is very necessary so that the socio-economic conditions of the local population are balanced with migrants, by improving education so that it can change their social and economic behavior.

\section{Operational definition of research:}

1. Investment is, is the realization of the amount of funds for Foreign Investment and Domestic Capital Security of the Regency/City of the Papua Province which are calculated annually based on the Constant Price in billion Rupiah (percent).

2. Government expenditure is, the amount of the capital expenditure budget issued by the regional government for all regencies/cities which is set in the State revenue and expenditure budget and the regional income and expenditure budget every year in billion Rupiah based on constant prices (percent).

3. Economic growth is, the development value of Gross Regional Domestic Product (GRDP), that is, the amount of aggregate output produced by districts / cities through increasing GDP based on constant prices (percent).

4. Migration is any effort and effort made by an individual or community group to enter a region with the aim and hope of finding opportunities and employment opportunities and business development in order to improve the welfare of the company and provit the company. 
5. Poverty rate is: the percentage of the population living below the poverty line, and calculated based on the percentage of the number of poor people per year.

\section{Methodology:}

Based on the approach and type of level, this study was designed as a verification research that aims to examine and test the existence of empirical theories of the relationships of the formulated variables. This type of research is in the form of explanatory survey and exprimental research.

Explained that experimental research aims to predict and explain things that occur or will occur between certain variables through speculation of controlling the relationship between these variables, so that differences can be found in one variabek or relationship and even the influence between these variables.

Furthermore, this causality research aims to investigate the possible causal relationship of a study or event or phenomenon that can be measured and try to explain the causality relationship between exogenous variables and endogenous variables. Thus, causality research is a level of verification research that is based on the nature of explanatory research which explains causality between variables.

The phenomenon of the relationship between variables in this study, will be measured through quantitative methods using multiple or multivariant regression analysis, or by using path analysis (path analisys) which is then described based on theoretical references and empirical studies which are certainly considered relevant to the topic of research,

This study shows 2 (two) different types of variables, namely exogenous variables and endogenous variables. Exogenous variable is an independent variable (predictor) in the form of investment, and government expenditure whose diversity is not influenced by modifiers in the system, where in this case it is determined as a beginner variable which is considered to have an effect on other variables. while the endogenous dependent is the Poverty Rate variable, each Regency / City whose diversity will be explained by other exogenous and endogenous variables in the model.

To answer the problems that have been raised, information is needed that has elements of validity. The types of information used are: 1. General description of the Papua Province according to BPS. 2. information on the amount of investment in Papua Province 2007-2017, 3). population and employment information in Papua Province 20072017. 4). Expenditure data for the Papua Provincial Government in 2007-2017. 5). Information on Gross Regional Domestic Product (GRDP), on the basis of Constant Prices (CP) 2000 Papua Province 2007-2017. 6). Information on Economic Growth on the basis of Constant Prices (CP) 2000 for 2007-2017. 7). Information on the Gini Index Ratio (Gini Rasio) in Papua Province, 2007-2017. 8). Information on the number of poor people in Papua Province 2007-2017.

While information collection is carried out directly at various agencies or related agencies, or institutions that are competent about statistical information. the information in question is in the form of publication data, publications, printed reports that are published regularly from various competent agencies, agencies or related institutions, in this case the regional Central Statistics Agency (BPS) of the Papua Province.The information processing techniques carried out are processing document consisting of basic document, processed document and analysis document obtained through 2 (two) ways, namely manual document processing and document processing using software toolsSPSS and Amos.

Therefore, the information used in this study is secondary data in the form of panel tools (hola data) which is a combination of 10 (ten) years time series data (2007-2017) with cross-section data of 29 Regencies/Cities in Papua Province.

The first and second stages in this study basically produce a system model of structural equations, namely an equation that describes the relationship between components of Investment (X1), and Government Expenditures (X2) on poverty levels (Y3) through Economic Growth (Y1) and Migration (Y2), with the form of equations, namely;

$\mathrm{Y} 1=\mathrm{f}(\mathrm{X} 1, \mathrm{X} 2)$

$Y 2=f(X 1, X 2)$

$\mathrm{Y} 3=\mathrm{f}(\mathrm{Y} 1, \mathrm{Y} 2, \mathrm{X} 1, \mathrm{X} 2)$ 
Information :

$\mathrm{X} 1$ = Investment

$\mathrm{X} 2$ = Government expenditure

$\mathrm{Y} 1=$ Economic Growth

$\mathrm{Y} 2=$ Migration

Y3 = Level Poverty

\section{Research Results and Discussion:}

Astronomical Location of the Papua Province:

Astronomically, Papua Province is located between $2^{\circ}, 25-9^{\circ}$ south latitude and between $130^{\circ}-141^{\circ}$ east longitude. Based on its geographical location, Papua Province has boundaries: the north is bordered by the Pacific Ocean: south of the Sea of Arauru: in the west it borders West Papua Province: and in the east it borders Papua New Guinea. Based on geography, the Papua Province is the largest province among the provinces in Indonesia with an area of $316,553.07 \mathrm{~km}^{2}$.

The breadth of the Papua Province is proportional to the number of administrative regions currently available. This is due to the development and progress and the aspirations of the people so that the administrative area of Papua Province continues to increase.

Administratively, since 1999 in accordance with Law Number 22 of 1999, the territory of the Papua Province has been divided into several districts in accordance with the demands of regional autonomy. At present the Papua Province has 28 regencies, and 1 municipality as the center of the provincial government. Of the 29 districts / cities spread around 541 districts with 153 villages and 4,635 villages.

Based on data from the Central Statistics Agency (BPS), it was explained that the average population growth rate of the Papua Province in 2016 to 2015 was 0.12 percent. And the average population growth of Papua Province in the last 10 years (Year 2007-2017) based on gender is still relatively dominated by male population, except in 2007, 2008, 2009 and in 2010 the percentage of population was dominated by women, each of which was 52, 67 percent to 52.81 percent with a ratio of 107.61 to 113.40 (every resident of 107.61 or 113.40 males has 100 female residents). While the percentage of the poor population of districts / cities in the Papua Province is presented in Table 1.

Table 1:-Percentage of Poor District / City Population in Papua Province 2007-2017

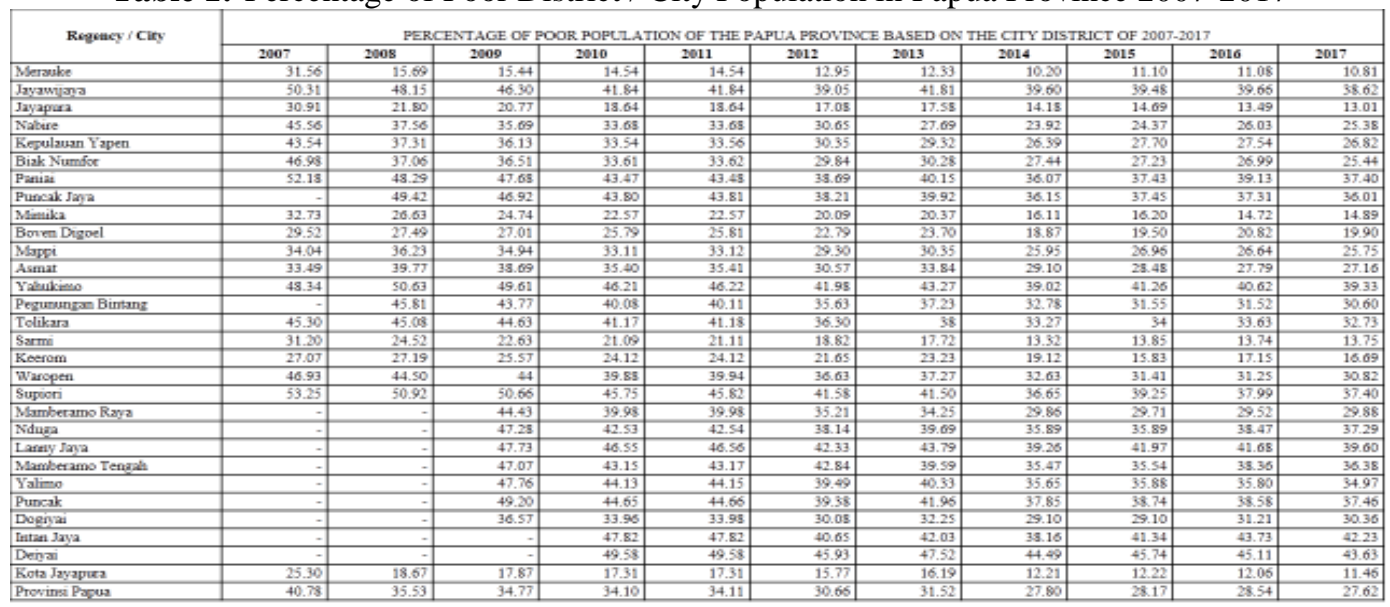

Information Source: Papua in Figures, Papua Province Central Statistics Agency (BPS). In the process of 2018

Based on the information in Table 1, it is explained that, the percentage of poverty levels of districts and cities in Papua Province is relatively high. Until 2017, the poverty rate in Papua Province reached 27.62 persent, and put Papua Province as a Province with a high level of poverty. 


\section{Description of Research Result Statistics:}

In an effort to analyze the influence of the determinants of Poverty Levels in the Papua Province, it is necessary to do a linear regression analysis simultaneously which aims to estimate the magnitude of direct and indirect influences. Therefore, in this simultaneous linear regression analysis the endogenous variables are Economic Growth (Y1), Migration (Y2) and Poverty Rate (Y3). While the exogenous variables consist of Investment (X1) and Government Expenditures (X2). Based on linear regression analysis simultaneously using equations, the calculation results obtained as shown in table 2 .

Table 2:-Results of Estimated Economic Growth Function (Y1), Migration (Y2), and Poverty Rate (Y3).

\begin{tabular}{|c|c|c|c|c|}
\hline Inter-Variable Influences & $\begin{array}{c}\text { Regression } \\
\text { Coefficien }\end{array}$ & t-Statistik & Probability & Significance level \\
\hline $\mathrm{X} 1===>\mathrm{Y} 1$ & $-0,047$ & $-1,954$ & 0,051 & Not significant \\
\hline $\mathrm{X} 1===>\mathrm{Y} 2$ & $-0,029$ & $-1,623$ & 0,105 & Not significant \\
\hline $\mathrm{X} 1===>\mathrm{Y3}$ & $-0,185$ & $-1,788$ & 0.074 & Not significant \\
\hline $\mathrm{X} 2===>\mathrm{Y} 1$ & $-0,119$ & $-0,771$ & 0,441 & Not significant \\
\hline $\mathrm{X} 2===>\mathrm{Y} 2$ & $0,245^{*}$ & 2,139 & 0,032 & significant \\
\hline $\mathrm{X} 2===>\mathrm{Y} 3$ & $6,465^{*}$ & 9,677 & 0,000 & significant \\
\hline $\mathrm{Y} 1===>\mathrm{Y3}$ & $-0,244$ & $-1,006$ & 0,315 & Not significant \\
\hline $\mathrm{Y} 2===>\mathrm{Y3}$ & $1,050 *$ & 3,212 & 0,001 & significant \\
\hline
\end{tabular}

Description: Test Results Using the Amos Version 24 Program

The estimation results of each variable can be explained as follows;

Direct Effect of Investment on Poverty Levels:

The direct effect of investment on the poverty level shows a negative effect that is not significant ( $t$ value of -0.781 and coefision value -0.039). This shows that an increase in investment has not been able to influence the level of poverty in the Papua Province.

\section{Direct Influence of Government Expenditures on Poverty Levels:}

The direct effect of Government Expenditures on Poverty Levels shows a significant negative effect ( $t$ value of 1.243 and coefision value of -0.425 ). This shows that government expenditure has not been able to influence the level of poverty in the Papua Province.

The Direct Effect of Economic Growth on Poverty Levels:

The direct effect of Economic Growth on Poverty Levels shows a significant positive effect (t value of 4.658 and coefficient value of 0.510 ). This means that economic growth does not affect the level of poverty.

\section{The direct effect of Migration on Poverty Levels:}

The direct effect of Migration on Poverty Levels shows a significant negative effect (t value of -6.218 and coefficient value of -0.907). This shows that every 1 percent increase in migration will reduce the poverty rate by 0.907 percent in Papua Province.

Indirect Effects of Investment on Poverty Levels through Economic Growth and Migration:

The indirect effect of investment on poverty levels through migration shows a significant negative. The significant negative effect comes from a significant positive relationship between Investment and Economic Growth ( $t$ value of 6.322 and coefficient value 0.113 ) which is then continued with a significant negative relationship between Migration and Poverty Level ( $t$ value of -6.218 and coefficient value of -0.907). This shows that investment has an effect on reducing poverty.

Indirect Effects of Government Expenditures on Poverty Levels through Economic Growth and Migration: In addition, the indirect effect of Government Expenditures on Poverty Levels through Economic Growth and Migration has a significant negative effect. The significant negative effect comes from the insignificant negating relationship between Government Expenditure and Economic Growth ( $t$ value of -0.7771 and coefficient value 0.119) which is then continued with a significant positive relationship between economic growth and migration ( $t$ value of 1.962 and coefficient value of 0.082) and a significant negative relationship between Migration and Poverty 
Level ( $\mathrm{t}$ value of -6.218 and coefficient value of -0.907 ). This shows that government spending through economic growth and migration has an effect on reducing poverty.

Indirect Effects of Government Expenditures on Poverty Levels Through Migration:-

In addition, the indirect influence of Government Expenditures on Poverty Levels through Migration shows a significant negative effect. The significant negative effect comes from the relationship between Government Expenditure and Economic Growth (t value of -0.7771 and coefficient value -0.119) which is then continued with a significant positive relationship between economic growth and migration ( $t$ value of 1.962 and coefficient value of 0.082 ) and significant negative relationship Migration and Poverty Level ( $t$ value of -6.218 and coefficient value of 0.907). This shows that economic growth through migration has an effect on reducing poverty.

\section{Analysis and Implications of Direct Investment Effects on Poverty Levels:}

The direct effect of Investment on Poverty Levels shows in significant negative effects. This shows that investment has not affected the level of poverty. This is in line with the results of research conducted by Aminah (2016) in his research that analyzed the effect of private investment and regional government spending on economic growth and poverty in Jambi Province.

\section{Analysis and Implications of Direct Investment Effects on Poverty Levels:}

The direct effect of Investment on Poverty Levels shows in significant negative effects. This shows that investment has not had a significant effect on the level of poverty. This is in line with the results of research conducted by Aminah (2016) in his research that analyzed the effect of private investment and regional government spending on economic growth and poverty in Jambi Province.

Research uses sequential document from 1985-2012. The analytical tool used is regression with the method "Ordinary Least Square" (OLS). The findings of this study indicate that private investment and local government spending have a positive impact on economic growth and reduce poverty in Jambi Province.

The implications of the results of this study indicate that to reduce poverty in the Papua Province investment must continue to be increased so as to reduce poverty. The coefficient of elasticity of investment variables towards the poverty level is negatively insignificant.

\section{Analysis and Implications of the Direct Effects of Government Expenditures on Poverty Levels}

The direct effect of Government Expenditures on Poverty Levels shows insignificant negative effects. This shows that government spending has not yet affected the poverty level. The results of this study are in line with Agussalim (2006) who conducted a study to analyze the extent to which government expenditure was able to reduce poverty, through the dynamics of growth and inequality in Indonesia during the period 1976-2004, using the simultaneous structural equation model method.The results of the study show, first, growth and decline in inequality are good for the poor. Second, poverty seems more responsive to growth than inequality. Third, education and health expenditures are policies that favor pro-poor poverty. Fourth, health expenditure has the greatest influence on all measures of poverty. Fifth, all macroeconomic variables, except investment, have an influence on poverty.

The meaning is, that the amount of government expenditure does not affect the high economic growth. Furthermore, the high and low economic growth does not affect the poverty level. This result is not in accordance with the initial hypothesis which states that government spending has a negative and significant indirect effect on the level of poverty through economic growth.

\section{Analysis and Implications of Indirect Effects of Investment on Poverty Levels through Economic Growth and Migration:}

The indirect effect of investment on poverty levels through economic growth and migration shows a significant negative effect. This shows that investment has a significant effect on the level of poverty through economic growth. The implications of the results of this study indicate that to reduce poverty in the Papua Province investment must continue to be increased so as to reduce poverty.

In addition, the amount of investment does not affect economic growth, and the amount of economic growth affects the high and low migration. Furthermore, the high and low migration will affect the level of poverty. 
The implication of the results of this study is that, the effect of investment on poverty levels is the flow of migration. Migration flows have a good influence on poverty levels. However, the flow of uncontrolled Migration will have an impact on the increase in population and the narrowness of employment. So that in the long run it can affect employment opportunities for local residents.

\section{Analysis and Implications of Indirect Effects of Government Expenditures on Poverty Levels through Economic Growth and Migration:-}

The indirect effect of Government Expenditures on Poverty Levels through Economic Growth and Migration shows a significant negative effect. This shows that government spending affects the level of poverty through economic growth and migration.

Theoretically, the regional government will be able to set a larger capital expenditure if the DBH budget is getting bigger, and vice versa, the smaller the capital expenditure will be determined if the DBH budget is getting smaller. DBH has a positive effect on Capital Expenditures (Wandira, 2013). Thus it can be concluded that the implication of the results of this study is that Special Allocation Funds are funds originating from the state budget allocated to local governments to finance special activities which are regional affairs and national priorities.

\section{Conclusions and recommendations:}

The structural model formed consisting of Government Investment and Expenditure is an exogenous variable, while Economic Growth, Migration and Poverty Levels are endogenous variables or variables influenced by exogenous variables. Based on the results of the analysis, the two exogenous variables each have a negative negative direct effect on the level of poverty and have a significant negative effect on the level of poverty through economic growth and migration.

Based on the comparison of the direct and indirect effects of the Investment variable on the Poverty Level variable, it generally shows that the Investment variable has a negative contribution to the poverty level but is not significant.This means that investment has not been able to reduce the level of poverty in the Papua Province. Therefore investment needs to be continually encouraged and the government must provide wider and more serious attention, including among others the alignment with investors by providing easier services and guaranteeing security and legal certainty. Furthermore, based on this model, it can be emphasized that in order to reduce poverty in Papua Province, local governments need to continue to increase government spending, especially capital expenditure, because government spending, especially capital expenditure, can directly or indirectly have a good influence on poverty levels.

By comparing the direct and indirect effects between the variables of Government Expenditure on the Poverty Level variable, it generally shows that the Government Expenditure variable has a negative but not significant contribution to the poverty level in the Papua Province. This means that even though the effect is not significant, it does not mean that government spending must be reduced. It should be noted that every additional budget for regional government expenditure in this case capital expenditure for infrastructure plays a very large role in the Papua Province, especially in increasing interest in investing and job creation and community empowerment. Therefore government expenditures, especially capital expenditure for infrastructure must continue to be increased.

By comparing the direct and indirect effects between the variables of Economic Growth on the Poverty Level variable, it generally shows that the Economic Growth variable has a significant positive influence on the level of poverty in the Papua Province. This means that economic growth cannot reduce the level of poverty in the Papua Province. The results showed a significant positive. However, economic growth is still needed because one of the indicators in overcoming poverty is economic growth.

The direct effect of the Migration variable on the Poverty Level variable shows a significant negative effect on the level of poverty in the Papua Province. This means that migration can reduce poverty in Papua Province. The results showed a significant positive. However, it does not mean that it must encourage migration. It should be noted that the effects of migration vary greatly, can have a good impact but can also have a negative impact. Uncontrolled flow of migration will cause a loss of opportunity for local people to get jobs. Other impacts are increased unemployment, crime, social disturbances and a population explosion. Therefore local governments must be wiser and wiser to address the benefits of the transmigration program policies offered by the central government. 


\section{References:-}

1. Agussalim, 2009. Reducing Poverty (A New Proposal for Indonesia). Nafa Cipta Litera Publisher Cooperates with the Development Policy and Management Study Center of Hasanuddin University, Makassar.

2. Aminah 2016, Analysis of the Effects of Private Investment and Expenditures of Regional Governments on Economic Growth and Poverty in Jambi Province Journal of Perspective of Regional Financing and Development Vol. 4 No. 2, October-December 2016 ISSN: 2338-4603 (print); 2355-8520 (online).

3. Arsyad, L., 1999. Development Economics. Fourth Edition. Yogyakarta: STIE YKPN.

4. Bungin, B., 2008 Quantitative Research Methodology, First Edition, Jakarta, Kencana Prenata Media Group.

5. Boediono. 2001. Macro economics. BPFE Publisher, Yogyakarta.

6. Blank, R. M., 2004. Poverty, Policy and Place: How Poverty and Policies to Alleviate Poverty Are Shaped by Local Characteristics. RPRC Working Paper.

7. Chambers, Robert, (1983). Rural Development, Putting the Last First, Longman: London

8. Dumairy. 1999. Indonesian Economy, Erlangga Publisher, Jakarta.

9. Dwiyanto, A. (2003). Governance reform and regional autonomy. Yogyakarta: Center for Population and Policy Studies at Gadjah Mada University.

10. Hagenaars, A. and Klaas de Vos., 1997. The Defenition and Mesurement of Poverty. The Journal of Human Resources.

11. Heeren, H. J. (1979). Transmigration in Indonesia. Jakarta: Indonesian Torch Foundation.

12. Horst, Siebert., 1969, Regional Economic Growth : Theory and Policy International Text Book Company, Scronton. Pennylvonia.

13. Khan, A, Rahman, 2007. Growth, Employment and Poverty : An Analysis of the Vital Nexus Based on Some Recent UNDP and ILO/SIDA studies. DESA working Paper.49.

14. Mubyarto, 1993. Ways to Combat Poverty. Tempo No. Edition 11 Year XXIII. Publisher, PT Grafiti Press, Jakarta.

15. Oyugi, LN., 2008. , Effects of Economic Growth on Poverty Reduction: Experience from Botswana, Kenya and Namibia, Southern and Eastern Africa Policy Research Network (SEAPREN), Working Paper, No 10, SEAPREN, Windhock.

16. Poli, W.I.M 2006. Voice of Heart That Empowers, Ideas for Community Empowerment in Jayapura Regency. Publisher, Reflection Library. Makassar.

17. Tarigan, R (2005). Regional Economy (Theory and Application) Publisher, PT. Bumi Aksara, Jakarta.

18. Todaro M P, 1999. Economic Development in the Third World (Translation of Munandar Haris), Publisher Erlangga.

19. Todaro M P, 2000. Economic Development, Addison Wesley Longman, Inc. New York. 